\section{CARBON FIBRE}

\section{ICI drops Plans}

THE prospects for a large scale British carbon fibre industry were dealt a severe blow last week. After an extensive survey of the possible market for carbon fibre, Imperial Chemical Industries Ltd has announced that it is to drop its plans for a $£ 5$ million factory to produce the material. It seems that the survey showed that there is little likelihood that production costs will be low enough to open up a broad industrial market for carbon fibre, and ICI is not interested in producing the material at a high cost for specialist application in the engineering industry.

This decision comes at a time when the prospects for carbon fibres seemed particularly promising. The Select Committee on Science and Technology recommended in March that a plant capable of producing 450 tons a year should be built as soon as possible, because it was convinced that production on this scale would bring the costs of carbon fibre down to about $£ 5$ per lb or even less, compared with the present price of about $£ 100$ per lb. Courtaulds announced last month that it had plans to build a plant of 100 tons capacity, and this was taken as an expression of confidence in the market potential of the material which paved the way for widespread speculation that carbon fibres would soon be competing for places in industries as diverse as motor car bodies and building materials. ICI believes, however, that if carbon fibres are ever to compete in those markets, production costs must be brought down to about $£ 2$ per 1 , and it seems that the survey indicated that costs would not even approach that figure.

At the moment, three companies-Courtaulds, Morgan Crucible and Rolls-Royce-hold licences from NRDC to manufacture carbon fibres, and two of these have made agreements with American companies for manufacturing and marketing the material in the United States. Rolls-Royce is at present using carbon fibre in specialist applications such as turbine blades. Behind the disappointment at the ICI decision obviously lies the fear that America could catch up with Britain in carbon fibre technology, and could ultimately exploit the market potential of the material where British industry has failed. This fear could lead to renewed suggestions that a fourth producer should enter the ficld in the shape of a state financed plant built either by the Atomic Energy Authority or the Royal Aircraft Establishment at Farnborough. There seems, however, to be little reason for doubting the validity of the ICI survey, which was carried out at a cost of $£ 100,000$ and involved extensive cooperation with the Atomic Energy Authority at Harwell.

The future of carbon fibres in British industry is likely to be the subject of a further inquiry by the Select Committee on Science and Technology when it is reconstituted in the next few weeks, and it will undoubtedly come under strong pressure to recommend that the government should increase its stake in the field. Mr Arthur Palmer, chairman of the select committee, described the results of the ICI survey as "very disappointing", and he acknowledged that the situation may have to be reviewed. Courtaulds is not in the least daunted by the ICI decision, however. It believes that carbon fibres have enormous potential in many markets, and sees the main con- straint as the lack of knowledge of how to use them. Courtaulds's production plant will be capable of producing about 25 tons a year during 1970 , at a cost of between $£ 15$ and $£ 85$, and the Jarger 100 ton plant will be commissioned when the market demands production on that scale. If Courtaulds's analysis of the possibilities for carbon fibres is correct, then ICI's decision may not be a bad one, because if a large scale plant were built now, advances in production techniques would soon make it obsolete, and the decision to intensify research on composites in general could pay off if carbon fibres ever secure a large market.

\section{RABIES}

\section{Mad Dogs and Englishmen}

Camberley in Surrey ought to be safe from rabies after the Ministry of Agriculture's two-day shoot of local wild life at the end of October. The hunt, intended to eliminate as far as possible any spread of infection from a dog called Fritz which died of the disease (see Nature, 224, 399; 1969), produced a bag of 130 animals, none of which showed symptoms of the disease. There is, however, some surprise that there have been no specific tests for the virus in the carcasses; it would, of course, have been too soon for overt signs of rabies to develop.

Although it is unlikely that any wild animals had become infected from the one dog known to be suffering, part of the value of the shoot was the hope that it would provide a concrete assurance that no other animal had caught the disease. Although a veterinary officer attended the hunt and was prepared to send suspect carcasses to the Ministry's Central Veterinary Laboratory at Weybridge, the animal bodies were simply incinerated-they seemed to be healthy.

The usual test for rabies is to demonstrate the presence of characteristic protozoon-like Negri hodies which occur in the cytoplasm of certain nerve cells of an infected animal and which contain the virus. In practice, these are sought in brain tissue, and a suspension can be injected into mice to test for virulence. Presumably the reason for not subjecting the Camberley killings to this procedure was the small chance of finding anything--but, because of the long incubation of the disease-usually 3 to 6 weeks, but sometimes much longer-it might have been worthwhile to examine a few samples.

There is no simple test for rabies in live animals, which means that there is no hope, for the time being, of introducing a spot check that could supplement or even in part replace the quarantine regulations. Moreover, vaccines are not entirely reliable-in Rhodesia, for example, where the Flury vaccine has been used since 1953, 115 cases of rabies were found in ten years among vaccinated dogs. The fact that the Camberley dog was the third to develop rabies, even after six months, does give weight to arguments that the length of quarantine should, if anything, be increased.

The causes of the latest case are at present the subject of an official inquiry (see Parliament in Britain, page 638). The outlook seems to be good. Camberley Common is being watched for the statutory six months, until next April, and any foxes that may reappear are likely to be shot; they are the main danger if the virus gets into the natural environment. The pet dogs of 